\title{
The Philippines, the East Asian "Developmental States" and Education: A COMPARATIVE ANALYSIS OF WHY THE PHILIPPINES FAILED TO DEVELOP
}

\begin{abstract}
After WWII, the economic prospects of the Philippines, then the second largest economy in Asia, were viewed positively but by the mid-1970s, it had become Asia's developmental puzzle for its failure to sustain economic growth. In contrast during the same period, regional neighbours, Hong Kong, Taiwan, South Korea and Singapore, achieved previously unknown levels of economic growth and were dubbed the 'East Asian Tigers'. This paper analyses the post war development of the Philippines, focusing on the role that education played, and contrasts it with the East Asian tigers. It is argued that the Philippines was distinctive in the state's failure to exercise strong central control, especially of the education system, which was neither harnessed to promote economic development nor national unity. The status quo that has its origins in a plantation economy prevailed, which ensured the country remained an unequal and impoverished democracy.
\end{abstract}

\section{Introduction}

The Philippines is a puzzle because in the 1960s it was viewed as the Asian country most likely to develop rapidly (Lande, 1965; Lucas, 1993; Martin, 1993) but as Table 1 shows its economy failed to take off, in marked contrast to its East Asian neighbours. By 2000, the Philippines even lagged behind the second phase of rapidly developing local economies such as Thailand and Indonesia - whose per capita GDP in the 1960s was only one-third of that in the Philippines (Terry, 2002; Yap and Balboa, 2008). The early optimism about the country's potential was based on both the relatively impoverished state of the post war economies of its neighbours and the nature of its own educational and political systems.

In the 1960s, the education system was considered one of the most developed in Asia (Cardozier, 1984; Lande, 1965; Swine ton, 1991). As shown in Table 2, the country had one of the highest rates of adult literacy, basic education completion, secondary education and higher education participation levels in the region. Thus Lande optimistically declared that "farsighted educational policies adopted by American officialdom prepared the way for rapid industrial growth at a later time by helping to create a labour force equipped by training and outlook to man modern industrial establishments" $(1965,325)$. The failure of the country to achieve rapid economic growth led Filipino scholars to pose the question, 'If we're so smart, why aren't we rich?' (de Dios et al, 1995)

The Philippine revolution in 1898 gave it independence from Spain. Immediately thereafter, the process of state formation commenced with the establishment of Aguinaldo's revolutionary government and the Malolos Congress, but was aborted a year later by the American occupation, which lasted until 1946. The USA paid the Spanish \$20million for the Islands in 1899. Nonetheless, the US introduced electoral democracy through the first election of the lower house of a bicameral national legislature in 1907 (Nelson, 2007), and a judicial/legal system patterned after the American model. This made it Asia's first democracy. Myrdal (1968) argued that the political conditions in the Philippines augured well:

"Representative government has a long history in the Philippines and would seem to be firmly established; the country has had the experience, rare in the region, of two changes 
in national leadership via the ballot. Under these circumstances, it would seem possible that politics could gain a broader democratic base by more organized participation on the part of the low income groups. This could well lead to the breakup of the present political power structure and the initiation of large-scale reforms, primarily those of an agrarian nature." (390)

These predictions did not materialize. Why did the Philippines miss out on the Asian economic boom(s)? There is a plethora of studies analyzing the success of the 'Tiger' economies, but a relative dearth of scholarly work comparing the Philippines with its neighbours and analyzing its failure to develop. This paper provides the first in-depth comparative analysis of the interface between education and the development of the Philippines with that in the East Asian Tigers. Our focus is on the economic dimension of development because, as indicated above, on many of the measures of human development and welfare (e.g. life expectancy, educational access and literacy) the Philippines was a leader in the region. Its failure was that it was unable to harness those conditions to improve the economic wellbeing of all of its citizens. We argue, following the extensive literature (Wade, 1990; Green, et al 2007) which highlights the critical role of the state in the rapid development of the tiger economies (rather than the influence of free market forces) that the root of the problem lay in the weakness of the state. Specifically we suggest that despite its democratic political system and high levels of educational access, the state was captured by a range of self interested groups and failed to prioritise economic development or the national interest. This was manifested in the education system, on which we focus, where the states policies were incoherent, not implemented, or subject to reversal.

\section{The East Asian Tigers}

Prior to focusing on the role of education we briefly review the range of explanations that have been advanced for the success of the Tiger Economies. Whilst education policies have been seen to be critical, they have generally been viewed as an element within a broader economic and political strategy pursued by the state. Three, often interconnected, strands of explanation are summarized below, which relate to: the historical, geo-political and cultural conditions; the economic; and the political dimensions.

It has been argued that the colonial legacies of the Tigers created conditions supportive of their later success (Booth, 2005; Litonjua, 1994). Singapore and Hong Kong benefitted from inheriting an infrastructure and system of governance that was relatively efficient and allowed the state to exercise its authority. Taiwan was under Japanese rule for fifty years (1895-1945), and the undivided Korea for thirty-five years (1910-1945).

Japan has been ascribed a critical role in the growth of the agricultural economies of Taiwan and South Korea, especially in the creation of an infrastructure that facilitated the state's capacity to control and govern. These colonies were transformed into extensions of the Japanese agricultural sector (Litonjua, 1994) to feed the growing needs of imperial Japan, ushering in an era of food security and mutual cooperation even after independence in 1945 (Angeles, 1992). Likewise, Japan would turn to South Korea and Taiwan for cheap labour when it began its industrialization at the start of the $20^{\text {th }}$ Century.

These post-colonial relations also facilitated the rise of the indigenous entrepreneurial class, who were sustained later by state-led and centralized approaches to education planning and management. Latterly, as the Tigers began to develop, they turned to Japan for strategies and policies to "borrow" in their quest to achieve rapid industrialisation and growth. Accordingly, 
Kasahara (2004) describes the Tigers' emulation of Japan's approach as the "flying geese model" of development.

East Asian post-war and post colonial history was defined by the region's new geopolitics, in which a mixture of regional tensions and the impact of the Cold War defined the West's relations with these states as bulwarks against the spread of Communism. Supported by aid, trade and technology transfer, these regimes flourished amidst strained relationships with neighbouring states (Morris, 1996; 1998). South Korea remains technically at war with the communist North after an armistice instead of a peace treaty was signed in 1953Abe, 2006). Singapore was expelled from the Federation of Malaysia after declaring independence in 1965 and continued to view Malaysia as a threat to its sovereignty for a while (ibid). China considers Taiwan as a renegade province after the nationalist Kuomintang fled there. Until the 1980s the government considered itself the legitimate government of the mainland. Hong Kong, which until 1997 was a British Colony, defined itself by reference to its distinctiveness from the communist mainland.

The cultural explanation has argued that the Tigers share a Confucian cultural heritage, which values and inculcates attributes such as diligence, filial piety and loyalty and has been conducive to both ensuring economic success and support for, or at least a willingness to sublimate, personal in favour of communal interests and an acceptance of the leadership of the benevolent state (Cummings, 1996; Tai et al, 1989; Tu et al, 1996). The argument echoes that of Weber, that the "Protestant ethic", which values diligence and abstinence, facilitated the industrialisation and growth of countries such as the UK and Germany. Weber also argued that China's failure to develop at that time was attributable to the effects of Confucianism.

The 1997 Asian economic crisis resulted in an appraisal of some of the claims for the success of the Tiger Economies, especially with regard to their shared traits and the virtues of 'Confucian societies'. For example, Kang (2003) points out that the much valued 'strong family ties' led to cronyism and corruption in Korean society. Abe (2006), using basic demographic data, argues against the classification of East Asian nations as 'Confucian States' or "Confucian Heritage Cultures." Abe notes that Taoism rather than Confucianism is prevalent in Taiwanese society; 50 percent of Koreans believe in Christianity; and Singapore is a multiethnic city-state. Whilst such explanations may be valid to explain the situation in a country, they have limited generalizability as they can neither explain the more recent economic growth of countries such as Malaysia or Thailand nor can they explain why, given these long-standing cultural traits, economic growth occurred when it did.

There are many strands of analysis in the economic dimension of the Tigers' success story, but there is a common recognition of the importance of the outward-oriented economic policies pursued and their capacity to respond quickly to changing economic circumstances (World Bank, 1993). However that focus on exports was preceded by a range of reforms, which created the conditions that allowed the economies to industrialize and focus on exports. Land reforms and agricultural productivity improvements in South Korea and Taiwan in the 1950s were followed by import substitution policies from the late 1950s to the early 1960s until their transition to export-oriented manufacturing during the middle and latter part of the 1960s.

Except for Hong Kong, the East Asian economies then shifted to industrial production through refining, chemicals, steel production and later shipbuilding in the late 1960s to early 1970s. Intensified competition in the late 1970s and early 1980s in the production of low cost manufactured goods threatened their competitiveness as they raced towards more skillsintensive, higher-end manufacture of electronic goods and components, including computer 
chips and personal computers. By the 1990s the emergence of China as a manufacturing economy led to a transition to services and researched-based areas of production, such as biotechnology, and (in the case of Singapore) as a regional service hub for transnational companies.

The 1993 World Bank report found no single model to explain how the East Asian economies had grown rapidly with low levels of income inequality. They identified as a common feature pragmatism and flexibility in policy-making. The high degrees of risk-taking and adaptability were attributed to bureaucracies insulated from political interference (Abe, 2006). The report identifies broad categories of policies that created the East Asian miracle (World Bank, 1993 p. 82-86). First, measures to ensure macroeconomic stability were introduced, by controlling inflation for example. Second, the government intervened when necessary, such as setting the interest rates in the capital markets and providing financial support and tariff protection for weak industries. Third, investment in both human and physical capital was prioritized. Fourth, policies converged towards openness to international trade. Finally, mechanisms and processes that encouraged private investment and competition were institutionalized. The report emphasizes that the East Asian bureaucracies got effective results through these policies by ensuring positive interaction and reinforcing feedbacks generated over a sustained period of time. A number of authors (Chang, 2002; Wade 1990) have argued that this depiction overstates the role of market forces and underestimates the powerful role played by the state.

These disparate explanations for the success of the Tigers outlined above are effectively integrated in their depiction as "Developmental States" (Donner et al, 2005; Woo-Cumings, 1999). The term developmental state was first used by Johnson (1982) to describe Japan's post war economic growth and at its core involves a strong government prioritizing economic growth as the overarching goal and pursuing a coherent strategy to achieve its goals through an efficient bureaucracy. The state's primary source of legitimacy was economic and individual rights were sometimes sacrificed to achieve the 'common good'. Levels of income inequality were relatively low whilst access to the fruits of economic growth and social mobility were largely meritocratic and primarily determined by school examination results. Myrdal (1968) outlines the economic dimension of what was the precursor of the developmental states, or as the World Bank terms it "soft authoritarianism", when he refers to 'strong states' which used economic planning and coordinated large-scale state intervention to anticipate the market rather than just to provide infrastructure.

Similarly, Castells $(1992,2000)$ argues that the geo-political crises and ongoing external threats experienced early in their industrialization led these countries to adopt developmentalism, a political-economic ideology and strategy characterized by strong state intervention. In effect, the government operated on a quasi war footing with the economy as the primary instrument of national defence. The authoritarian political structure was reinforced by the Confucian tradition that promotes respect for authority and a deep sense of morality and civic duties. Moreover, Confucian societies have been attributed with putting a high premium on scholarship and public service, borne out of prestige and honour attributed to service in royal and imperial courts in ancient times.

In sum, the cornerstone of the East Asian Tigers' success was their economic transition from the 1960s to the 1990s, from import substitution to export industries. But the success of economic and social policies was anchored in the interventionist role of the state and it was not Adam Smith's 'invisible hand' of the market at work, but the 'iron hands' of the state, especially in Taiwan, Singapore and South Korea. 
Education was a key element in the strategies employed by the developmental state as it was harnessed to provide the skills the economy required and to create the social cohesion, sense of national identity and patriotism which the single-minded quest for economic advancement required. Sung (2006) argues that the states policies, especially in Singapore, created 'developmental workers' whose commitment to upgrading their skills and productivity was vital in supporting economic growth. The national education systems of the Tigers displayed distinctive features, especially in the 1960s and 70s when economic development was in its infancy. There was very strong central state control of schooling. Common curricula were made available to pupils and their access to schooling was based on their academic ability accessed via highly competitive examination systems. School curricula were uniform and designed to develop both the skills needed by the economy and to inculcate attitudes and values that were deemed to support social cohesion and loyalty to the state (Lall and Vickers, 2009). This state control was also reflected in strong curricular policies on the medium of instruction, which were used, with the exception of Hong Kong, to put in place national unifying languages.

Finally, education has been very much at the centre of national economic planning of the East Asian states (Cummings, 1995). The growth and expansion of the different levels of the education system was sequential, with mass primary schooling being achieved before the expansion of secondary schooling, and lastly of higher education (Morris, 1995, 1996). The state encouraged private providers to meet the demand for schooling, especially at the early childhood and higher education levels, but in parallel, exercised strong regulatory control of the sector. These periods of school expansion were almost synchronized with the periodic reengineering of their economies. In addition the system was perceived as fair and parents busied themselves in supporting and encouraging their children to work hard and maximise their examination results. More recently, as these countries have faced fresh challenges from a new phase of rapidly emerging nations, especially China, and the Asian economic crisis, their governments have engaged in wholesale reforms of the education systems, with the goal of ensuring their future economic competitiveness. Examples are the 'Learning to Learn' reform introduced in Hong Kong in 2000 and the 'Teach Less Learn More' reform introduced in Singapore in 2004.

At the higher education level, science and technology courses were prioritised (Cummings, 1995). The strong bureaucracies of the Tigers facilitated a progressive budgetary support for education, coordinated manpower forecasting for education planning, and governmentindustry-academe partnerships.

The above portrayal has provided a brief overview of the various factors which have been identified as contributing to the tiger's successful economic development. A number of caveats are necessary to minimise the risks of ignoring the negative aspects of developmental states and generalising across nations. Firstly, it is important to recognise that the strong and authoritarian role of the developmental states and their single-minded pursuit of economic development was not without costs. There were negative consequences for other aspects of development especially in the early period of economic take off. Human rights, especially those of individuals and minority communities were often trampled on in pursuit of the states vision of the national interest; democracy, freedom of speech and minority languages were suppressed; and schools specifically were used to promote the states messages which, inter alia, discouraged independent or critical thinking and taught forms of ethno-nationalism which came close to being xenophobic. Secondly, whilst there were commonalities in the approaches of the Tiger economies which have been highlighted above there were also significant variations. Specifically, the case of Hong Kong does not fit comfortably as a classic 
developmental state as the colonial government: was tolerated by the population; did not attempt to promote a national identity; faced a free press and tolerated freedom of speech; and had difficulties implementing policies which faced substantial opposition (Morris and Adamson, 2010). However, as with the other Tigers, the Hong Kong government exerted strong central control of schooling to ensure it was not used for subversive purposes. More importantly, the government's source of legitimacy was, to an even greater degree than in the other Asian Tigers, based wholly on its capacity to ensure the growth of both the economy and the community's living standards. Further, as a society whose population were mainly economic and political refugees from the Mainland, or their descendants, a form of Developmental psyche emerged in which economic development was prioritized by the community. Finally, the experience over the last fifteen years of the first Developmental State, namely Japan, which has experienced economic stagnation for over a decade, is a salutary reminder that the patterns of economic growth achieved in the past are no guarantee of future performance.

\section{The Philippines}

Below we provide a brief analysis of the overarching economic and political conditions that have defined the country's development in the post war period. Subsequently, we focus on the education system. The discussion covers: the restored American- sponsored Commonwealth (1944- 46); the 4 elected governments (including Marcos' first term) of what is termed the Third Philippine Republic (1948-1969), the Marcos regime's New Society (1969-1986) and Aquino's revolutionary government in 1986 which constituted the Fourth Republic (19861992). To date, the Fifth Philippine Republic (1992-present) has had 4 elected governments with the current President Aquino's term ending in 2016.

During the colonial period (1899-1946), the country was developed as a plantation economy exporting agricultural products (sugar, hemp and tobacco) mainly to the USA. The Americans, who needed the support of the landed elite, reinforced the stratified patterns of land tenure (Litonjua, 1993:14) by selling large tracks of Spanish friar estates to wealthy Filipino families, who transformed the sequestered lands into cash crop plantations (Dolan, 1993).

Whilst the Americans dismantled the feudal system of land ownership in Taiwan and South Korea in the post-war period, the Philippines feudal structure was consolidated (Angeles, 1992; Litonjua, 1994). Succeeding governments would attempt to institute land reforms (Bello, 2009) but with limited effect. The World Bank (1993) traces the failure of the agrarian programme to the ability of powerful groups to capture the state and influence the country's economic policy to protect their own interests. Additionally, the report highlights the weak nature of the Philippine bureaucracy, whose deference to politicians and other interest groups resulted in an agrarian reform law riddled with loopholes and whose enforcement was nearly impossible.

Aside from reinforcing the status quo in terms of land ownership, the Americans ensured that funds for war reconstruction were tied to disadvantageous economic pre-conditions (Constantino, 1978). The 1946 Trade Act defined a relationship which greatly favoured the USA. Most controversial was the establishment of quotas on Philippine exports to the US and the "parity" provision that granted US citizens equal economic rights with Filipinos (Constantino and Constantino, 1978) These conditions have been viewed as constraining the development of the economy (Bello, 2009; Constantino, 1978) and emasculating the confidence of local industrialists which affected the over-all direction of industrial and enterprise development. 
The Philippines' post-war geopolitics was, as with the rest of East Asia, dominated by the Cold War and its strong relationship with the US, which involved it hosting the biggest US bases in Asia from 1947 until 1993. The country's ongoing economic, political and military dependency on the US has been viewed as tantamount to neo-colonialism. Although the economy greatly benefited from US aid due to the Military Bases Agreement of 1947 (Constantino and Constantino, 1978), a negative balance of trade led to the 1949 economic crisis, which triggered the 'oligarchic plunder' of war rehabilitation funds to pay for duty-free imports (de Dios and Hutchcroft, 2003:47). The government responded by instituting import and foreignexchange controls that lasted until the early 1960s (Dolan, 1993). This intervention invigorated manufacturing industry in the country. It became the flagship sector of the economy and grew from 10.7 percent of GDP in 1948 to 17.9 percent in 1960 (de Dios and Hutchcroft, 2003) and was the envy of South East Asia (Bello, 2009). Manufacturing output and exports exceeded those of Taiwan and South Korea, but that period was the peak of its economic performance (Krinks, 2002).

The oligarchs again seized the opportunities to gain control of licenses, create monopolies and enrich themselves (de Dios and Hutchcroft, 2003). The oligarchic system nurtured what was later referred to as 'crony capitalism' with the ascent of Marcos to power in 1965. Family members and business associates of the 'conjugal dictatorship' (1972-1986) were given monopolies and cartels, which stifled the growth and competitiveness of the Philippines export industries. Thus, the era of import substitution was, as with the plantation economy, dominated by a small oligarchy. The bureaucracy was rendered futile and economic policies were not shaped by the challenges and difficulties of the economy but by narrow interests.

Marcos ruled until 1986 and via martial law from 1972 to 1984 . Krinks (2002:2) argues that his regime was the most developmentalist government in Philippine history and the declaration of martial law was necessary to remove political and bureaucratic obstacles to development. In 1972, Marcos sought to emulate the East Asian economic miracle by attempting a transition from import substitution towards export-led industrialization (Litonjua, 1994:19). But the global economy was already in a downturn and 'the Philippines was completely unprepared for its sudden entry into a highly competitive world market' (McCoy, 1983 p. 142-43). Under martial law the country's development strategies remained incoherent, as 'there was continued promotion of exports, but at the same time continued protection of import substitution firms' (de Dios and Hutchcroft, 2003:49) - a majority of which were owned or controlled by Marcos and his wife's cronies and relatives.

Marcos' ambitious development programmes (e. g. rapid industrialization, mining, construction and public utilities) were financed through heavy foreign borrowing (Overholt, 1986) and relied on state institutions, including the military, to implement them. By the time he was overthrown the government was bankrupt (Balisacan and Hill, 2003) and succeeding governments would use 10 percent of GDP (Boyce, 1993) just for servicing the debt. Marcos failed miserably in this experiment as he used the state apparatuses for personal gain.

With the failure to develop the economy, a policy to export labour emerged as an official economic development strategy from 1974. This was intended as a short term measure to address unemployment problems as export-oriented growth was slowing down (Ruiz, 2006). However, it became a permanent policy for subsequent administrations. Today, the number of Filipinos working abroad is approximately 9 million or 10 percent of the population, one of the biggest diaspora populations in the world contributing almost 19 billion US\$ (approximately $10-12 \%$ of GDP) in 2010 to the economy (Remo, 2011). 
Thus the Philippine state, even when run as a dictatorship, was not used as a springboard for economic development (Koike, 1988), but rather as a vehicle for patronage. This has been explained by reference to Weber's work by Hutchcroft (1991), who argues that the Philippine state has been a patrimonial state since the introduction of electoral democracy in 1946, where the 'administration is treated as a purely personal affair of the ruler and political power is considered part of his personal property' (415). This 'personalistic' form of governance is entrenched across the political establishment, from village chiefs to senators. This practice is also rampant in the supposedly apolitical bureaucracy, with department secretaries using their offices for their national campaigns, or lower rank officials usurping power for personal gains (Chua, 1999; Reyes, 2010).

Marcos' dictatorship was replaced by the EDSA ${ }^{1}$ mass movement in 1986. Subsequent attempts to reform the economy have stalled in the face of a mixture of opposition from the powerful oligarchy and/or as a result of the government's own incompetence and corruption. The latter was most apparent in Estrada's regime, which was characterized as a period of gangster cronyism and mafia capitalism. Bello (2009:4) argues that a legacy from the Marcos dictatorship is a strong suspicion, and sometimes paranoia, towards any attempts by the state to reform or change the status quo. There is a seemingly reflex action by civil society, intelligentsia, and the Catholic Church against strong policy actions by the state. The country became the epitome of Myrdal's 'weak state' characterized by the weak implementation of laws, a politicized military and bureaucracy, uncooperative civil society, and a citizenry that lacks cohesion.

Accordingly, Bello (2009) described the Philippines as the "anti-developmental state" and blames what he calls the 'EDSA system' for the series of political crises that haunted the post Marcos administrations. He argues:

...with the rationale of discouraging tyranny, the American pattern of a weak central authority coexisting with a powerful upper class social organization ("civil society" in today's parlance) was reproduced in the Philippines, creating a weak state that was constantly captured by upper class interests and prevented the emergence of the activist "developmental" state that disciplined the private sector in other societies in post-war Asia (3-4).

Similarly, Almonte (1994:9) describes the political system as: ' ... a democracy of pressure groups because the state lacks sufficient authority. Extreme competition in influencing the policy-making process results in the widespread politicization of society.' Frequently the state's policies have been reversed by recourse to the constitution and a legal system that is based on the American model, which was designed to curtail the state's central authority.

In their analysis of the extra-constitutional removal of Estrada in 2001, de Dios and Hutchcroft (2003:63) argue it shows how 'institutions themselves were weak, corruptible, and susceptible to capture, even in their normal state' (original italics). They argue that the changeover from Estrada to Arroyo was resolved through the invocation of a higher, extra-constitutional logic, with 'the Supreme Court reaching deep down to retrieve the most elemental of governance principles, salus populi suprema lex'roughly translated as "the welfare of the people is the

${ }^{1}$ Epifanio de los Santos Avenue (EDSA) is a major highway in the middle of Metro Manila where millions of civilians converged to support the military uprising in February 1986. 
supreme law"(Doronila, 2001). This legal principal echoes the credo of the East Asian developmental states.

Whilst the developmental state initially operated as an outright autocracy or a very limited democracy, the Philippines state extolled participatory democracy but in practice is an elitist democracy with weak state institutions. Finally, in contrast to the Philippines, the developmental states changed as the political and economic contexts changed, such as South Korea's and Taiwan's successful transition from autocratic military rule to democratic civilian rule after achieving economic stability in the 1980's.

In sum, Philippine economic policies and strategies in the post war period were controlled by the narrow interests of an oligarchy that has its roots in the plantation economy. The political system has similarly been captured by self-interested groups and resulted in a bureaucracy and institutions of governance that are highly politicized, personalized, and ineffective.

\section{Education in the Philippines}

The pattern of governance outlined above was mirrored in educational policies and provision. In contrast to the situation in the Tiger countries, the Philippine state failed to exercise control of the education system. For the last sixty years, the state has negotiated with powerful interest groups - the Catholic Church, private education providers, and external institutions such as the World Bank, business groups, and private publishers of textbooks. The weakness of the state was reinforced by post -Marcos governments which sought to limit the role of the state. Thus the new constitution developed in 1987 institutionalized the decentralization of education, which resulted in the dismantling of the central governance of education.

We contrast the role of education to that in the Tiger countries with reference to the following policy areas which have been identified (Fagerlind and Saha1989; World Bank, 1993; Green, et al, 2007) as critical in supporting economic development, namely: national identity formation, education and the economy, population growth and higher education. We also examine a feature which is distinctive in the Philippines, the role of education in supporting labour migration.

\section{National Identity Formation}

Within the Tiger countries school curricula (with the exception of Hong Kong), especially in the subjects of Social Studies, Civics and History, were directly controlled and harnessed for the purpose of indoctrinating pupils into a strong form of national identity (Lall and Vickers, 2009). This often involved creating or highlighting: a sense of common lineage, shared ancestors, national foes, national heroes and suffering/potential threats at the hands of foreign oppressors. Whilst the Philippines did not indulge in such political indoctrination the outcome was the emergence of what Constantino (1978) describes as an amorphous national identity and weak nationalist consciousness. This is consistent with Doronila's (1989) findings, in her seminal work, that a majority of students $(95 \%)$ given the chance, would choose a different nationality than Filipino and ranked the Philippines third (after the US and Japan) among the countries to be 'admired, lived in and defended.' In parallel, most Filipinos in a 1998 language survey did not believe in the idea of showing nationalism through the use of a common language of instruction in schools (Gonzales and Sibayan, 1988 in Gonzales, 1998). 
This disposition towards a 'Filipino' national identity is influenced by almost 50 years of education reforms financed by loans and grants from aid agencies (Bautista et al, 2008), which have used the school curriculum to promote their own priorities. This is most evident in the social studies curriculum, which includes history, civics and citizenship education. The state's failure to use the curriculum to create a sense of national identity is most marked in the way the country's relationship with the US is portrayed. Since the 1980s, textbooks financed by the World Bank portrayed the Americans as "accidental" colonizers (Constantino, 1982) a recurring controversy which resurfaced in 1997 and in 2009 (Tubeza, 2010). Similarly, the most widely-used history textbook in both public and private schools avoids reference to the War of Independence against the US. As Diokno (2010) comments,

They call it an 'alitan (quarrel)' as if it's just a lover's quarrel. It was a war with so many dead on both parties, particularly on our side. There were atrocities, torture, the water cure, all of that. And yet they just call this a quarrel ....It was the first war of liberation in all of Asia.

Wurfel (1988:24) describes the nature of the national identity portrayed by schools as a "variety inoffensive to the colonial master".

Historically, the state also had to contend with the Church when it did attempt to use schools to develop a sense of national identity. In 1956, the Church campaigned successfully against the Rizal Law, which mandated the compulsory study of the life and writings of Jose Rizal (who, along with Andres Bonifacio, led the revolt against the Spaniards). The government wanted pupils to study his original works but the Church objected. A 'compromise' was reached by using a censored version of Rizal's 'anti-friar' novels (Locsin, 1956), which were markedly less critical of the role of the Church in supporting colonization (Constantino and Constantino, 1978).Thus attempts to create a national hero have been thwarted by sectoral interests.

Finally, the weakness of the state to control the curriculum was compounded by the dismantling of the government's monopoly over textbook production. In 1995, the privatization of the textbook industry was legislated partly to address the chronic problem of shortages and the well-documented corruption in the education bureaucracy (cf. Carino et al, 1998). However, this merely resulted in 'decentralized' corruption fostered by unscrupulous publicprivate partnerships (Reyes, 2009) and the provision of multiple, often low quality titles for the same subjects (Lontoc, 2007).

Bautista, et al (2008:22) summarized the situation when they opined that the education bureaucracy had 'relinquished control over the curriculum and its content decades ago.'

\section{Education and the Economy}

The dominant attitude of Filipinos towards the purpose of education is reflective of the American model of educational development, as described by Cummings (2003), which stresses a successful individual as the ideal type and consequently is seen as an individual right guaranteed by a succession of American-inspired constitutions. This individualism is also manifested in how Filipino scholars position education in the context of economic development. It is still portrayed as the individual Filipino's tool for poverty alleviation by increasing their opportunities for employment (de Dios et al, 1995; Balisacan and Hill, 2003). Thus, Filipino scholars tend to portray education more as an aspect of poverty alleviation (e.g. Herrin and Pernia, 2003) and social development (e.g. Sanchez-Robielos, 1999), together with 
population, health, sanitation issues, in their analysis of the economy. This is in contrast to the East Asians practice which saw education as a tool for national development.

Marcos in his two-decade rule was the only post-war leader to make explicit attempts to establish a strong link between educational and economic progress. In 1969, he set up a commission to survey Philippine education guided with the 'belief that the economic and social survival of development of the nation was dependent on education' (Clarke, 1977:61). In 1972, through his 'New Society' project, he decreed that 'education must be transformed so that it can become an instrument for the economic and social transformation of the country (ibid).' It was also the first time that a long term plan (10 years) was formulated for the education system. Upon the declaration of Martial Law in 1972, schools were designated as the "vital agency in achieving the desired reform in the New Society' in which human resource development was linked to economic growth .Sadly this resulted in education servicing the one growing sector of the economy, the export of workers.

Currently, the country suffers from a labour-skills mismatch and graduate unemployment. The abolition of the National College Entrance Examination (NCEE), which led to unregulated access to tertiary education, is being blamed (Esplanada, 2007). Many of the unemployed have degrees in teacher education, the humanities and social sciences. In parallel the Philippines exports graduates in medicine, nursing, engineering and other professional fields who are needed domestically. Higher education expanded without any centralized planning or effective system of quality assurance. In 2007, out of the 2.6 million unemployed, some 1.1 million were college graduates and 650,000 technical-vocational jobs were available in the local market, because the applicants lacked the required technical vocational skills.

In contrast to the major systemic reforms pursued by the Asian Tigers the Philippines has engaged in promoting what has been termed 'projectized reforms' (PHDN, 2009). This involves a reliance on an array of small scale disjointed education projects that start and end in pilot activities and never translate into comprehensive or national reforms. Bautista et al (2008) describe the process thus:

These reform efforts yielded unsatisfactory results because they were 'decisions ... made out of urgency or exigency, instead of long-term considerations. Thus, education reform often resembles relief operations that hurriedly address obvious gaps and plug problematic holes in the system (5).

This model of education management is a classic case of externally-induced reform (Cummings and Williams, 2005), principally driven by the main donor, the World Bank. From a highly centralized system, the Department of Education has been pushed by aid agencies to decentralize since the 1990s, culminating with the decentralised-sectoral reform approach adopted in 2006 and funded by a loan from the World Bank. As the 2009 PHDN reports, 'in the last 20 years, foreign donor agencies did not only fund these [reform] projects, they also initiated, nurtured, monitored and saw them through their completion.' (23).

\section{Education and Population Growth}

The level of population growth in the Philippines has been consistently the highest in East Asia as illustrated in Table 1. In 2000, the Philippine Human Development Report stated that 'the most fundamental problem of the education system is that the rate of annual population growth 
is still 2.3\% ' (Gonzales, 2000:39). More recently, the 2010 Education for All report highlighted that this resulted in increasing class sizes and declining education expenditure per child and warned that the Philippines is bound to fail in achieving universal primary education by 2015 (UNESCO, 2010). Despite this, government initiatives to introduce a comprehensive family planning programme were consistently and successfully opposed by the Catholic Church. Most post-Marcos leaders feared losing support if they contravened the Vatican decrees about family planning. More recently this tension has resurfaced with a stalemate between the Department of Education and the Catholic Church, which again successfully blocked the attempt in 2009 to introduce a sex education curriculum that promoted birth control.

Today, the Catholic Church is more influential, especially in the overwhelmingly private higher education sector where they are the largest provider (Gulosino, 2003). Since 2000, they have been in a position of power with three prominent Catholic educators appointed to lead the Presidential Council on Education and the Department of Education.

\section{Higher Education}

As shown in Table 2, the Philippines expanded higher education provision from the 1950s so that by 1965 nearly 19\% of the age cohort attended universities. However, in the absence of a strong state, the expansion has been largely in areas weakly linked to the country's economic needs and has resulted in both a large pool of unemployed college graduates, which rose from $8.5 \%$ in 1980 to $14.8 \%$ in 2000 , and the sector orienting itself to prepare students to join the ranks of migrant workers (Ruiz, 2006).

Policies, especially relating to higher education, were often challenged and reversed by recourse to the courts by sectoral interests. For example, a 1993 Supreme Court decision concluded that the state's attempts to control access to higher education, through the NCEE, contravened the academic freedom of institutions to decide whom to admit. This effectively curtailed the capacity of the state to control this sector.

The Marcos government was the first to introduce in 1972 the 'streaming' of secondary education graduates through the NCEE, which was the only assessment system that provided national measures of achievement. It was intended to address the rising problem of graduate unemployment and the imbalance between labour market needs and the training of graduates (Cardozier, 1984). But early critics viewed this as a form of 'coercion' and means of 'control' and feared that the government would steer the nation's manpower where it wished (Clarke, 1977:60), which was partly confirmed when Marcos decreed the labour export policy in the 1970s (Ruiz, 2007). Additionally, the implementation of NCEE was part of a response to an International Bank for Reconstruction and Development (IBRD) mission, which 'was convinced that the Philippine education system was not focused on the needs of a rapidly growing economy....education is regarded more as a constitutional right than an instrument of economic progress' (Clarke, 1977:61)

The NCEE case is also indicative of how the influence of the private higher education sector has grown over the years into a lobby group who have successfully protected their interest with patronage from powerful politicians. This sector challenged the government and as a result the state lost control of the private higher education sector, as evidenced by the rapid expansion of private colleges and universities from 259 in the late 1940s to 1,665 in 2002, one of the highest rates of privatization in the world (Gulosino, 2003). Finally, the state allowed the private sector to ensure its own quality and manage the accreditation of colleges and universities (Arcelo, 
2003).The sector grew unhampered driven by the profit motive and even acted as conduits for the state's labour export policy - effectively abetting the transformation of the Philippines into an 'emigration state'(Ruiz, 2006).

\section{Education for Migration}

The states failure to establish a national identity or language has sustained what Constantino (1987) described as the continuing 'miseducation of the Filipinos' and fostered education's role as a tool for migration. He argued:

English introduced the Filipinos to a strange, new world. With American textbooks, Filipinos started learning not only a new language but also a new way of life, alien to their traditions and a caricature of their model...(they) learned the lives of American heroes, sang American songs, and dreamt of snow and Santa Claus....The lives of Philippine heroes were taught but their nationalist teachings were glossed over. Spain was the villain, America was the savior. (:47)

After independence, this portrayal was reinforced by World Bank-funded textbooks, which depoliticized colonial history, extolled American values and forged a 'dollar mystique' in young Filipino minds (Constantino, 1982). This, along with the poor employment prospects and returns, has contributed to a fascination with living 'outside' the Philippines, especially in the USA, and the desire to finish a 4-year college course and work 'abroad.' One major consequence of this pressure is that school and university curricula have increasingly been designed to prepare graduates for working overseas. Constantino argues:

Philippine academic and technocratic policy makers were prisoners of American methods and norms. The standards of education were such that its products were more attuned to the needs of a developed country than their own, hence the brain drain (Constantino, 1974:49).

The desire to emigrate has also created a strong bias for 4-year university education and an inferior valuation of vocational-technical education.

By the 1990s the educational system still did not have clear policies on the 'brain drain' issue (Swinerton, 1991) with the situation described as "out of control" (Tubeza, 2011). But a prominent Secretary of Education described Filipino migration as a viable development strategy, as a 'source of foreign exchange and a natural way of population control' (Gonzales, 1992: 21).

\section{Conclusion}

What we have shown in this paper is disjuncture in the approaches of the Philippines and the East Asian Tigers at both the generic level of political governance and in the way education was governed. The Philippines has had weak leaders, an absence of government control, and a political system that allowed vested interests to capture and neutralize decision-making. Essentially, the Philippine democratic state displayed none of the features of the East Asian developmental states.

In the area of education, the country has relied on policies that markedly contrast with those implemented in the Tiger countries. As Myrdal (1971:351) postulated: 
Effective reform of the educational system must assume a form of government control of educational institutions. There is no point in devising any over-all plan for the development of the educational system unless the government exerts its authority to ensure realization of the plan.

The Philippine state never successfully harnessed education to serving either the needs of the economy or to creating a common national identity. In contrast, the East Asian Tigers harnessed schooling to achieving economic development and to create a common national identity. Whilst the governments of the Tiger economies imposed, often in the face of opposition, controversial policies in areas such as population control, the medium of instruction and limiting the provision of private schooling, the Philippine state was reduced to negotiating with other powerful institutions. The result was often a mixture of a failure to make policy or to implement it.

The stark contrast demonstrated in the historical comparison outlined above is however far clearer than the implications for the future that arises from that comparison. At one level the self evident implication is that the Philippines can learn from the Developmental States of East Asia by: abandoning a broken political system, replacing it with a "strong state", and a reduction in the tendency to rely on the USA as a model of best practise. However such a conclusion risks making the naïve assumption that what worked elsewhere nearly half a century earlier (and has since changed) could be now adopted successfully in the Philippines. It is questionable if Filipinos would now be willing to accept a strong state, or its achievement would result in serious opposition and conflict. Similarly, the post war environment which was dominated by the cold war, facilitated (or at least tolerated) the emergence of strong states has been replaced by a very different world order. That order is portrayed by Chang (2008) as one which seriously disadvantages those poorer nations that are now attempting to join the ranks of developed nations. It is the prevalence of the more generic and universal features of bad governance, especially the high levels of corruption and the capture of the state by special interest groups, rather than the creation of a developmental state per se, that needs rectifying. Without that any policies pursued by the state, including attempts to strengthen the role of the state, will face an ongoing crisis of legitimacy.

\section{REFERENCES}

Abe, M. (2006) The Developmental State and Educational Advance in East Asia, Educate: The Journal of Doctoral Research in Education, 6 (1), pp 6-12.

Almonte, J. (1994) Politics of Development in the Philippines, Kasarinlan: Philippine Journal of Third World Studies, 9 (2 and 3), pp.107-117.

Angeles, L. (1992) Why the Philippines Did Not Become a Newly Industrializing Country. Kasarinlan: Philippine Journal of Third World Studies, 7 (2), pp. 90-120.

Arcelo, A. (2003) New Trends in Higher Education. In pursuit of continuing quality in higher education through accreditation: the Philippine experience, Paris: UNESCO International Institute for Educational Planning

Balisacan, A. and Hill, H. (2003) An Introduction to the Key Issues, in: Balisacan, A. and Hill, H. (Eds), The Philippine Economy: Development, Policies, and Challenges, pp. 3-44, Oxford: Oxford University Press. 
Bautista, MCR et al (2008) When Reforms Don't Transform: Reflections on Philippine

Education, University of the Philippines Centennial Lecture Series, November 12, 2008, UP-NISMED, Quezon City, Philippines.

Bello, W. (2009) The Anti-Development State: The Political Economy of Permanent Crisis in the Philippines (2009 edition), Manila: Anvil.

Booth, A. (2005) Did it really help to be a Japanese colony East Asian economic performance in historical perspective, Asia Research Institute Working Paper No. 43 (June) (accessed 9 May 2011, http://www.ari.nus.edu.sg/docs/wps/wps05 043.pdf)

Boyce, J. K. (1993) The Philippines: The Political Economy of Growth and Impoverishment in the Marcos Era, Honolulu: University of Hawaii Press.

Cardozier, V. R. (1984) Public Higher Education in the Philippines, International Review of Education, 30 (2), pp. 193-198.

Cariño, L. et al (1998) Initiatives taken against corruption: The Philippine case, New York: United Nations Development Programme.

Castells, M. (1992), Four Asian Tigers With a Dragon Head: A Comparative Analysis of the State, Economy, and Society in the Asian Pacific Rim, in R. Appelbaum and J.Henderson (eds) States and Development in the Asia Pacific Rim. London: Sage.

Castells, M. (2000) End of Millennium (2nd Edition), Oxford: Blackwell.

Chang, Ha-Joon (2002) The East Asian Model of Economic Policy, in: Huber, E. (end) Models of Capitalism: Lessons for Latin America, pp 197-236, University Park: Pennsylvania State University Press.

Chang, Ha-Joon (2008) Bad Samaritans: The Guilty Secrets of Rich Nations and the Threat to Global Prosperity, London: Random House

Chua, Y. (1999) Robbed: An investigation of corruption in Philippine education, Quezon City: Philippine Centre for Investigative Journalism.

Clarke, A. (1977) Education and the New Society in the Philippines, Compare: A Journal of Comparative and International Education, 7 (1), pp. 57-65.

Constantino, L. (1982) World Bank Textbooks: Scenario for Deception, Quezon City: Foundation for Nationalist Studies.

Constantino, R. (1974) Identity and Consciousness: The Philippine Experience, Quezon City: Foundation for Nationalist Studies.

Constantino, R. (1978) Neo-colonial Identity and Counter consciousness, White Plains, New York: Sharpe.

Constantino, R. (1987) The Miseducation of the Filipino, in: Schirmer, D. and Shalom, S.R. (Eds) (1987) The Philippines Reader: A History of Colonialism, Neo-colonialism, Dictatorship, and Resistance. South End Press.

Constantino, R. and Constantino, L. (1978) The Philippines: the continuing past. Quezon City: Foundation for Nationalist Studies.

Cummings, W. (1995) The Asian Human Resource Approach in Global Perspective, Oxford Review of Education, 21 (1), pp. 67-81.

Cummings, W. (1996) Asian Values, Education and Development, Compare: A Journal of Comparative and International Education, 26 (3), pp. 287-303.

Cummings, W. (2003) The Institutions of Education: A Comparative Study of Educational Development in the Six Core Nations, Oxford: Symposium Books. 
Cummings, W. and Williams, J. (2005) International Development Models for Educational Reform, Asia Pacific Journal of Education, 25 (2), pp. 125-143.

de Dios, E. and Hutchcroft, P. (2003) Political Economy, in: Balisacan, A. and Hill, H (Eds) The Philippine Economy: Development, Policies, and Challenges, pp. 45-73, Oxford: Oxford University Press

de Dios, E. et al (1995) If We're So Smart, Why Aren't We Rich: Essays on Education and Economic Success, Manila and Quezon City: Congressional Oversight Committee on Education.

Diokno, M.S. (2010) Errors of Omission (Interview) in: Tubeza, P., Erroneous textbooks still rated perfect by DepEd, Philippine Daily Inquirer Wire Service http://newsinfo.inquirer.net/inquirerheadlines/nation/view/20100621-276733/Erroneoustextbooks-still-rated-perfect-by-DepEd (accessed 9 May 2011).

Dolan, R. E. (Ed.) (1993) Philippines: A Country Study (4th ed), Washington, D.C: Library of Congress.

Donner, R. et al (2005) Systemic Vulnerability and the Origins of Developmental States: Northeast and Southeast Asia in Comparative Perspective, International Organization, 59 (Spring 2005), pp. 327-361.

Doronila, A. (2001) Peoples coup: Bloodless, constitutional, democratic. Philippine Daily Inquirer Wire Service, http://www.ngy.1st.ne.jp/ ieg/icrm/2001/01/01n991.htm (accessed July 9, 2009).

Doronila, M. L. (1989) The Limits of Educational Change: National Identity Formation in a Public Elementary School, Quezon City: University of the Philippines Press.

Esplanada, J. E. (2007) Tech-voc program tops agenda of education department, Philippine Daily Inquirer Wire Service, http://newsinfo.inquirer.net/breakingnews/ nation/view/20070612-70769/Techvoc_program_tops_agenda_of_education_department (accessed 9 August 2009).

Fagerlind, I. and Saha, L. (1989). Education and National Development: A Comparative Perspective ( $2^{\text {nd }}$ Ed), Oxford: Pergamon Press.

Gonzales, A. (1992) Higher education, brain drain and overseas employment in the Philippines: towards a differentiated set of solution, Higher Education, 23, pp. 21-31

Gonzalez, A. (1998) The Language Planning Situation in the Philippines, Journal of Multilingual and Multicultural Development, 19 (5), pp. 487- 525

Gonzales, A. (2000) Philippine basic education1999-2004: Analysis, recommendations, and plans, in Philippine Human Development Report 2000, pp. 37-45. Manila: Human Development Network and the UN Development Programme.

Green, A. et al (2007) Education and Development in a Global Era: Strategies for Successful Globalisation, London: Department for International Development.

Gulosino, C. (2003) Evaluating Private Higher Education in the Philippines: The Case for Choice, Equity and Efficiency. In Occasional Paper No. 68, National Center for the Study of Privatization in Education, New York City: Teachers College, Columbia University

Herrin, A. and Pernia, E. (2003) Population, Human Resources, and Employment, in: Balisacan and Hill (eds.) The Philippine Economy: Development, Policies, and Challenges, pp. 283-310. Manila: Ateneo de Manila University Press.

Human Development Reports (2003, 2004, 2005, 2010), United Nation Development Programme (UNDP) 
Hutch croft, P. D. (1991) Oligarchs and Cronies in the Philippine State: The Politics of Patrimonial Plunder, World Politics, 43, pp. 414-450.

Johnson, C. (1982) MITI and The Japanese Miracle: The Growth of Industrial Policy, 19251975, California: Stanford University Press.

Kang, D. C. (2003) Transaction Costs and Crony Capitalism in East Asia, Comparative Politics, 35 (4), pp. 439-458.

Kasahara, S. (2004) The Flying Geese Paradigm: A Critical study of Its Application to East Asian Regional Development, United Nations Conference on Trade and Development, Discussion Paper \# 169, April.

Krinks, P. (2002) The Economy of the Philippines: Elites, Inequalities and Economic Restructuring, London: Routledge.

Lall, M. and Vickers, E. (2009) Education as a Political Tool in Asia, London: Routledge.

Landé, C. (1965) The Philippines, in: Coleman J. (Ed) Education and Political Development, Princeton: Princeton University Press.

Litonjua, D. (1994) Outside the den of dragons: The Philippines and the NICs of Asia, Studies in Comparative International Development., 28 (4), pp. 3-30.

Locsin, T. (1956) The Church Under Attack, The Philippine Free Press Online http://philippinesfreepress.wordpress.com/2006/05/05/the-church-under-attack-may-51956/ (accessed 27 May 2011).

Lontoc, J. F. (2007) Straightening out the kinks: A look into the DepEds textbook policy, The Forum - July-August 2007 - (Vol 8 Issue 4) http://www.up.edu.ph/upforum2.php?i=155\&pg=206\&pgidx $=\&$ pgmax $=1 \&$ issue $=20$ (accessed 9 May 2011).

Lucas, R.E. Jr. (1993) Making a miracle, Econometrica, 61, pp 251-272.

Maddison, A. (2006) The World Economy, Development Centre of the Organisation for Economic Co-operation and Development. Paris, France.

Martin, P. L. (1993) Migration and Trade: The Case of the Philippines, International Migration Review 27 (3).

McCoy, A. (1983) In Extreme Unction: The Philippine Sugar Industry, in: Political Economy of Philippine Commodities. Quezon City: Third World Studies Center.

Morris, P. and Adamson, B. (2010) Curriculum, Schooling and Society in Hong Kong, Hong Kong: The Hong Kong University Press.

Morris, P. and Sweeting, A. (1998) 'The Little Asian Tigers: identities, differences and globalisation'. In K. Sullivan (ed.), Education and Change in the Pacific Rim (pp. 203223). Oxford: Triangle Books

Morris, P. (1996) Asia's Four Little Tigers: A Comparison of the Role of Education in Their Development, Comparative Education Review, 2 (1), pp. 95-109.

Morris, P. and Sweeting,A.(1995) Education and Development in East Asia, New York: Garland Press.

Myrdal, G. (1968) Asian Drama: An Inquiry into the Poverty of Nations, London: Allen Lane.

Myrdal, G. (1971) Asian Drama: An Inquiry into the Poverty of Nations (abridged version by King, S. (ed.), Twentieth Century Fund. Pantheon Books.

Nelson, R. (2007) The Philippine Economic Mystery, The Philippine Review of Economics, 44 (1), pp. 1-33.

Orbeta, A. (2003) Education, labor market and development: a review of the trends and issues in the Philippines for the past 25 years, Philippine Institute for Development Studies.

Overholt, W. H. (1986) The Rise and Fall of Ferdinand Marcos, Asian Survey, 26 (11), pp. 1137- 1163. 
Philippine Human Development Network (PHDN) (2000, 2009). Philippine Human Development Reports.

Remo, M. (2011) Overseas Filipinos sent record \$18.8B in 2010; Philippine Daily Inquirer

Wire Service http://business.inquirer.net/money/topstories/view/20110215-

320454/Overseas-Filipinos-sent-record-188B-in-10 (accessed 15 February 2011).

Reyes, V. (2009) Case study of implementation amidst corruption linkages: The National

Textbook Delivery Program (TDP) of the Philippine Department of Education, Journal of Education Policy, 24(4), pp. 515-35.

Ruiz, N. (2006) Made for Export: Labor Migration, State Power, and Higher Education in a Developing Society, Paper presented at the annual meeting of the The Midwest Political Science Association. Palmer House Hilton, Chicago, Illinois, http://www.allacademic.com/meta/p99755_index.html (accessed 25 May 2009).

Ruiz, N. (2007) The Emigration State: Labour Export as Development Policy, Paper presented at the Annual Meeting of the International Studies Association. Town \& Country Resort and Convention Centre, San Diego, California, USA

http://www.allacademic.com/meta/p211099_index.html (accessed 29 November 2008).

Sanchez-Robielos, M. T. (1999) Human and social development in the Philippines towards achieving NIChood, in: Gonzalez, E. (ed.) Reconsidering the East Asian economic model: what is ahead for the Philippines?, Pasig City: Development Academy of the Philippines.

Swinerton, N. (1991) Philippine higher education: toward the twenty-first century, New York: Praeger Publisher.

Sung, J. (2006). Explaining the economic success of Singapore: the developmental worker as the missing link, UK: Edward Elgar Publishing.

Tai, H. et al (1989) Confucianism and Economic Development: An Oriental Perspective?, Washington, D.C.: The Washington Institute Press.

Taiwan Ministry of Education online database (www.moe.gov.tw)

Terry, E. (2002) How Asia Got Rich - Japan, China, and the Asian Miracle, New York: M.E. Sharp Publishing.

Tu, W. et al (1996) Confucian Traditions in East Asian Modernity: Moral Education and Economic Culture in Japan and Four mini-Dragons, Cambridge: Harvard University Press.

Tubeza, P. (2010) Erroneous textbooks still rated perfect by DepEd, Philippine Daily Inquirer Wire Service http://newsinfo.inquirer.net/inquirerheadlines/nation/view/20100621 276733/Erroneous-textbooks-still-rated-perfect-by-DepEd (accessed 9 May 2011).

Tubeza, P. (2011) Brain drain worse, study shows, Philippine Daily Inquirer Wire Service http://newsinfo.inquirer.net/inquirerheadlines/nation/view/20110215-320343/Brain-drainworse-study-shows (accessed 15 Feb 2011)

UNESCO (2010) Education for All Global Monitoring Report 2010.

Wade, R. (1990), Governing the Market: Economic Theory and the Role of Government in East Asian Industrialization, New Jersey: Princeton University Press.

World Bank (1993) The East Asian Miracle (Main Report), New York: Oxford University Press.

Woo-Cumings, M. (ed.) (1999) The Developmental State, New York: Cornell University Press. 
Wurfel, D. (1988) Filipino Politics: Development and Decay, Quezon City: Ateneo de Manila University Press.

Yap, J and Balboa, J. (2008) Why has the Philippines lagged? [Online]. Available at: http://www.eastasiaforum.org/2008/10/05/why-has-the-phillipines-lagged (accessed 19 June 2009). 
Table I. Key Indicators of Selected Asian Economies

\begin{tabular}{|c|c|c|c|c|c|c|c|c|c|c|}
\hline \multicolumn{4}{|c|}{ Population growth rate } & \multicolumn{4}{|c|}{$\begin{array}{c}\text { per capita GDP } \\
\text { (1990 international Geary-Khamis } \\
\text { dollars) }\end{array}$} & \multicolumn{3}{|c|}{ GDP growth rate } \\
\hline & $1913-1950$ & $1950-1973$ & $1973-1998$ & 1950 & 1973 & 1990 & 2001 & $1913-1950$ & $1950-1973$ & $1973-1998$ \\
\hline Hong Kong & 4.21 & 2.79 & 1.87 & 2218 & 5695 & $|754|$ & 21259 & - & 8.13 & 6.21 \\
\hline Malaysia & 2.01 & 2.64 & 2.35 & 1559 & 2079 & 5132 & 7756 & 3.54 & 4.88 & 6.61 \\
\hline Philippines & 2.22 & 3.04 & 2.48 & 1070 & 1764 & 2224 & 2412 & 2.23 & 5.79 & 3.08 \\
\hline Singapore & 3.16 & 3.88 & 1.88 & 2219 & 4439 & 14365 & 21011 & 4.71 & 7.93 & 7.45 \\
\hline South Korea & 0.71 & 2.16 & 1.25 & 770 & 1954 & 8704 & 14673 & 0.30 & 8.13 & 7.31 \\
\hline Taiwan & 2.24 & 2.96 & 1.39 & 924 & 2980 & 9886 & 16214 & 2.87 & 9.81 & 6.77 \\
\hline Thailand & 2.28 & 3.08 & 1.61 & 817 & 1694 & 4629 & 6383 & 2.23 & 6.87 & 6.59 \\
\hline
\end{tabular}

Sources: Maddison (2006)

Table 2. Education Data of Selected Asian Economies

\begin{tabular}{|c|c|c|c|c|c|c|c|c|c|c|c|c|c|c|c|}
\hline & \multicolumn{3}{|c|}{ Adult Literacy rate } & \multicolumn{4}{|c|}{$\begin{array}{c}\text { Primary level enrolment } \\
\text { (gross ratio) }\end{array}$} & \multicolumn{4}{|c|}{$\begin{array}{l}\text { Secondary level enrolment } \\
\text { (gross ratio) }\end{array}$} & \multicolumn{4}{|c|}{$\begin{array}{l}\text { Tertiary level enrolment } \\
\text { (gross ratio) }\end{array}$} \\
\hline & 1980 & 1990 & 2003 & 1965 & 1975 & 1985 & $\begin{array}{l}2001- \\
2009\end{array}$ & 1965 & 1975 & 1985 & $\begin{array}{l}200 I- \\
2009\end{array}$ & 1965 & 1975 & 1985 & $\begin{array}{l}2001- \\
2009\end{array}$ \\
\hline Hong Kong & & $89.7^{a}$ & $93.5^{b}$ & 103 & 123 & 105 & 101 & 29 & 50 & 71 & 83 & 5.4 & 10.4 & 13.3 & 34.3 \\
\hline Malaysia & 69.52 & 80.7 & 88.7 & 92 & 94 & 101 & 98 & 28 & 45 & 53 & 69 & 1.9 & & 5.9 & 29.7 \\
\hline Philippines & 83.32 & 91.7 & 92.6 & 113 & 105 & 107 & 108 & 41 & 56 & 64 & 81 & 18.8 & 20.1 & 24.9 & 27.8 \\
\hline Singapore & 82.91 & 88.8 & 92.5 & 105 & 110 & 108 & & 45 & 53 & 59 & & 9.9 & 9.2 & 13.6 & \\
\hline South Korea & & $95.9 \mathrm{a}$ & $97.9 \mathrm{~b}$ & 101 & 109 & 97 & 104 & 35 & 59 & 92 & 96 & 6.2 & 9.8 & 34.0 & 96.1 \\
\hline Taiwan & & & & & $100 c$ & 99 & $100^{d}$ & & $74 c$ & 90 & $99 d$ & & $15.4 \mathrm{c}$ & 20.8 & $77.4^{\mathrm{d}}$ \\
\hline Thailand & 87.98 & 92.4 & 92.6 & 78 & 84 & 96 & & 14 & 25 & 30 & & 1.5 & 3.5 & 19.0 & \\
\hline
\end{tabular}

Sources: Orbeta (2003); UNDP- Human Development Reports 2003, 2004, 2005, 2010; Taiwan Ministry of Education online database (for all Taiwan data)

Notes: a. 1990 data, source: HDR 2004; b. 2001 data, source: HDR 2003; c. 1976 data, source:Taiwan Ministry of Education online database; d. data average 200I-09 (authors' computation), source:Taiwan Ministry of Education online database 